\title{
Terminating Cover Crops Effectively for Weed Suppression ${ }^{1}$
}

\author{
Pratap Devkota, Michael J. Mulvaney, and David Wright ${ }^{2}$
}

Cover crops have shown numerous benefits in conventional and organic crop production systems, particularly in the coarse, sandy soils of Florida (Wright et al. 2017). If managed appropriately for production system goals, cover crops reduce soil erosion by wind and rain, as well as nutrient leaching and runoff. Cover crops also enhance nutrient cycling, increase soil organic matter content, improve soil moisture, and generally enhance soil health, resulting in a greater crop yield.

After establishment, cover crops can reduce weed establishment and survival by competing for light and other resources needed for plant growth. Moreover, after termination, cover crop residue acts as a mulch to suppress weed establishment for several weeks into the crop season. When utilizing cover crops for weed suppression, one important consideration is effective termination before planting the main crop. A major issue with improper termination is that the cover crop can become problematic and compete with the main crop, like other weeds. However, proper planning of the termination timing and method can minimize these issues and maximize the benefits of cover crop use.

\section{Cover Crop Termination Timing}

For optimum weed suppression, the cover crop termination timing needs to be based on the crop species and its growth stage. Termination of the cover crop should be delayed so that the highest possible biomass is achieved to aid in weed suppression, but it should be done prior to the development of mature/viable seeds. In southern states (Florida, Alabama, Georgia, Mississippi, etc.), termination at 2-3 weeks before planting the main crop also allows enough time for soil moisture recharge by rainfall. However, to maximize nitrogen contributions from legume cover crops to a subsequent crop, planting of the subsequent crop should occur soon after termination. Table 1 provides the appropriate growth stages for terminating various cover crops.

\section{Cover Crop Termination Methods Herbicide Application}

Herbicide application is the most common cover crop termination practice for conventional systems. It is important to consider several aspects when terminating cover crops with herbicide application.

1. This document is SS-AGR-449, one of a series of the Agronomy Department, UF/IFAS Extension. Original publication date February 2021. Visit the EDIS website at https://edis.ifas.ufl.edu for the currently supported version of this publication.

2. Pratap Devkota, assistant professor, Agronomy Department, UF/IFAS West Florida Research and Education Center; Michael J. Mulvaney, assistant professor, Agronomy Department, UF/IFAS West Florida Research and Education Center; and David Wright, Extension specialist, cropping systems and conservation tillage, professor, Agronomy Department, UF/IFAS North Florida Research and Education Center; UF/IFAS Extension, Gainesville, FL 32611.

The use of trade names in this publication is solely for the purpose of providing specific information. UF/IFAS does not guarantee or warranty the products named, and references to them in this publication do not signify our approval to the exclusion of other products of suitable composition. Use herbicides safely. Read and follow directions on the manufacturer's label.

The Institute of Food and Agricultural Sciences (IFAS) is an Equal Opportunity Institution authorized to provide research, educational information and other services

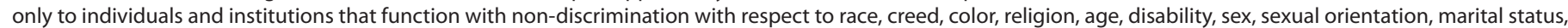

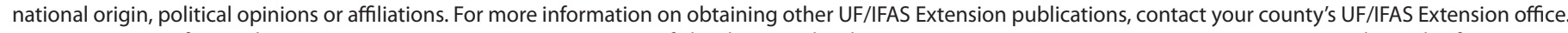
U.S. Department of Agriculture, UF/IFAS Extension Service, University of Florida, IFAS, Florida A \& M University Cooperative Extension Program, and Boards of County Commissioners Cooperating. Nick T. Place, dean for UF/IFAS Extension. 
1. Cover crop family: There are several cover crop families, such as small grains (grass species), legumes, and mustards. Herbicides need to be selected carefully based on the specific cover crop because herbicide response varies among these crop families and species. Herbicide selection is especially important in fields planted with mix of two or more cover crop types-a common practice in many areas. Additionally, cover crop growth stage is a critical factor to consider. To achieve proper termination, herbicides need to be applied so that the cover crop does not mature past a specified growth stage (as listed in Table 1). For a cover crop mix, multiple herbicide products might need to be tank-mixed to achieve an effective kill of all the cover crop species.

\section{Main crop after cover crop: If residual herbicide products} will be tank-mixed for cover crop termination, then effects on the subsequent crop (main crop) should be considered. Residual herbicide products usually have longer plant-back restrictions that might limit the crop choices for the subsequent planting. Therefore, using herbicide products labeled for burndown or preplant application for the subsequent crop is important.

\section{Selecting and tank-mixing herbicide products: Herbicide} products can be contact or systemic types. Contact herbicides such as paraquat (Gramoxone, etc.), glufosinate (Liberty), or saflufenacil (Sharpen) do not move in the plant; therefore, they only affect the plant parts where droplets deposit. Poor coverage can limit contact herbicide performance and compromise cover crop termination. Enhance spray coverage by using nozzles that produce medium droplets, spraying at a higher volume (greater than 15 gallons per acre), applying herbicide at a higher rate (i.e., higher end of the labeled rate range), and adding surfactants. Systemic herbicides such as glyphosate (Roundup and various others), 2,4-D or dicamba (various products), or grass herbicides (Select Max, etc.) are taken up and translocated to the growing points of the plant; as a result, complete coverage is not as important for their effectiveness. However, cold weather, cloudy conditions, or generally poor growth (due to drought, deficiencies, etc.) may delay herbicide performance, and termination of the cover crops might take longer.

It is a good practice to tank-mix herbicide products with preemergence (PRE) and postemergence (POST) activity, but be cautious about potential negative effects. If herbicide products used in the tank-mix are not compatible, reduced herbicide activity may result. For instance, tank-mixing of herbicides such as atrazine, metribuzin, diuron, or chlorimuron reduces glyphosate activity on cereal rye, but tank-mixing 2,4-D, dicamba, or saflufenacil does not affect glyphosate performance. While tank-mixing PRE or residual herbicides, be mindful of the subsequent crop and plant-back restrictions. Various POST herbicides could be tank-mixed (Table 2) to kill cover crops effectively and to broaden the weed control spectrum.

\section{Roller-Crimper Termination}

A roller-crimper is an implement that can be mounted on the front or back of a tractor. The implement is usually a hollow cylinder (filled with water to increase weight) with welded blades on the outside to crimp stems. This implement crushes and creases stems to facilitate cover crop termination. Cover crop species such as hairy vetch, barley, triticale, cereal rye, and oats can be terminated effectively using the roller-crimper method (Table 3 ). The following considerations are important when using a roller-crimper to terminate cover crops.

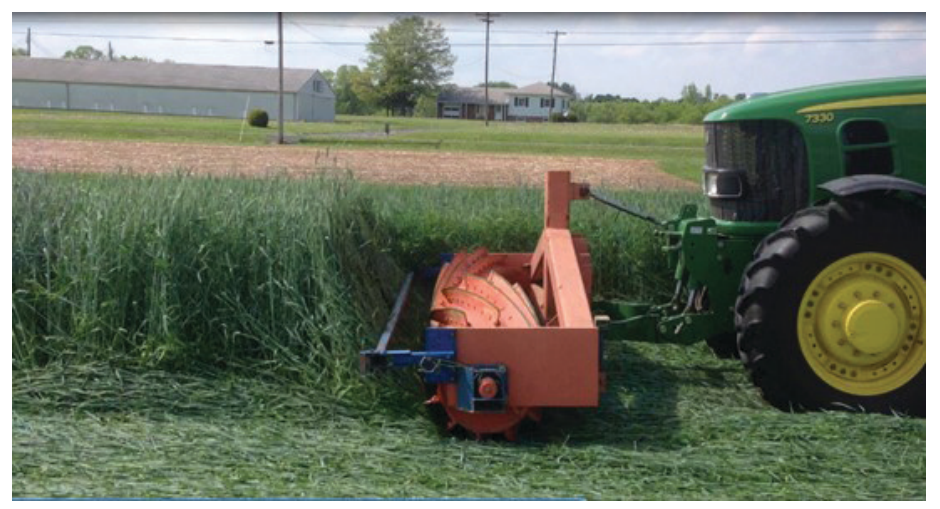

Figure 1. The roller-crimper rolling down a cereal rye cover crop in a no-till field.

Credits: USDA Integrated Weed Management Resource Center Website

1. Cover crop stage: Effective termination with a rollercrimper is highly dependent upon the appropriate growth stage of a cover crop species. For cereal rye, rollercrimper termination should be implemented between $50 \%$ anthesis and early milk stages (Padro et al. 2019). If cereal rye is rolled too early (before $50 \%$ anthesis), it can still produce new tillers and seeds. Likewise, if rolled too late (after the milk stage), seed heads can continue to develop and mature. For hairy vetch, appropriate timing for roller-crimper termination is from full bloom to early pod set (Padro et al. 2019). If a cover crop mix (e.g., legume and cereal rye) is planted, roller-crimper termination could be challenging due to differences in growth habit between the two species.

2. Mechanical considerations: Roller drum angle relative to the center beam (or travel direction) can impact the effectiveness of roller-crimper termination. For example, when termination was performed with roller drums 
perpendicular to travel direction (to rye rows), the rye rebounded after rolling. However, when the roller drum was operated at a 75-degree angle to the center beam, the rye was tossed diagonally, and fewer plants rebounded (Little 2019). In addition to better termination, the latter technique enhanced soil surface coverage with residue after cover crop termination. Some growers roll the cover crop parallel to rows, and others commonly roll at angles up to 45 degrees. Regardless, planting the main crop in the direction of rolling will limit residue accumulating and dragging through the planting equipment.

\section{Tillage}

Tillage is an option for cover crop termination, but it is not preferred. Multiple tillage passes are required to effectively terminate cover crop species that have deep root systems (such as clovers). Moreover, tillage termination is impractical for no-till or minimum-till systems where cover crop residues are maintained on the soil surface to prevent soil erosion and enhance soil health benefits. Even in strip-till systems, it is better to first terminate the cover crop with an herbicide application and follow up with the strip tillage.

\section{Conclusion}

Regardless of method, it is important to effectively terminate cover crops to prevent them from spreading as a weed during the subsequent crop season. The best practice for cover crop termination is to select an appropriate termination method and to implement it at crop-specific growth stages. It is also important to conduct follow-up scouting to ensure that cover crops are fully terminated. Follow-up scouting will help to identify skipped cover crop patches, escapes, or regrowth that might need spot application for complete termination. Overall, a properly managed cover crop can suppress many annual weed species and contribute to an effective weed management program.

\section{References}

Bosak, E., and V. Davis. 2014. "Cover Crop Termination." University of Wisconsin Extension. Wisconsin Weed Crop Science 204. Accessed on September 15, 2020. https://fyi. extension.wisc.edu/covercrop/terminating-cover-crops/

Little, R. 2019. "A Roller-Crimper for Cover Crop Termination and Weed Suppression." Accessed on September 20, 2020. https://cropwatch.unl.edu/2019/roller-crimper-covercrop-termination-and-weed-suppression
Padro, B. B., J. Wallace, M. Barbercheck, R. Hoover, C. Keene, and W. Curan. 2019. "Terminating Cover Crops with a Roller-Crimper in Organic Grain Rotations.” Accessed on September 28, 2020. https://extension.psu.edu/ terminating-cover-crops-with-a-roller-crimper-in-organicgrain-rotations

Palhano, M. G., J. K. Norsworthy, and T. Barber. 2018. "Evaluation of Chemical Termination Options for Cover Crops.” Weed Technology 32:227-235. https://doi. org/10.1017/wet.2017.113

Whalen, D. M., M. D. Bish, B. G. Young, S. P. Conley, and D. B. Reynolds. 2020. "Herbicide Programs for the Termination of Grass and Broadleaf Cover Crop Species." Weed Technology 34:1-10. https://doi.org/10.1017/wet.2019.73

Wright, D. L., C. Mackowiak, and A. Blount. 2017. Cover Crops. SS-AGR-66. Gainesville: University of Florida Institute of Food and Agricultural Sciences. https://edis.ifas. ufl.edu/aa217 
Table 1. Various cover crop types and their appropriate growth stages for termination.

\begin{tabular}{|l|l|l|}
\hline \multicolumn{1}{|c|}{ Cover Crop Type } & \multicolumn{1}{|c|}{ Cover Crop Species } & \multicolumn{1}{c|}{ Growth Stage for Termination } \\
\hline \multirow{2}{*}{ Small grain/grass types } & Annual ryegrass & Tillering-Early flowering \\
\hline & Cereal rye & Booting-Soft dough stage \\
\hline & Oats & Jointing-Booting stage \\
\hline & Winter wheat & Jointing-Booting stage \\
\hline \multirow{2}{*}{ Legume types } & Crimson clover/peas & Early bloom stage \\
\hline & Winter pea & Vegetative stage \\
\hline \multirow{2}{*}{ Mustard types (Brassica spp.) } & Hairy vetch & Early flowering stage \\
\hline
\end{tabular}

Table 2. Effective POST herbicide options for terminating various cover crops. (Adapted from: Palhano et al. 2018; Whalen et al. 2020). Contact: Weed Specialist (Pratap Devkota, UF/IFAS West Florida Research and Education Center, Jay, FL).

\begin{tabular}{|c|c|c|}
\hline Cover Crop & Herbicide Option & $\begin{array}{l}\text { Herbicide Rate } \\
\text { (fl oz/acre) }\end{array}$ \\
\hline \multirow[t]{2}{*}{ Cereal rye $^{1}$} & Roundup PowerMax (or similar) & $22-32$ \\
\hline & $\begin{array}{l}\text { Roundup PowerMax (or similar) } \\
+ \\
\text { Select Max (or similar) }\end{array}$ & $\begin{array}{l}22-32 \\
+ \\
16\end{array}$ \\
\hline \multirow[t]{3}{*}{ Winter wheat ${ }^{1}$} & $\begin{array}{l}\text { Roundup PowerMax } \\
\text { (or similar) }\end{array}$ & $22-32$ \\
\hline & $\begin{array}{l}\text { Roundup PowerMax (or similar) } \\
+ \\
\text { Select Max }\end{array}$ & $\begin{array}{l}22-32 \\
+ \\
16\end{array}$ \\
\hline & $\begin{array}{l}\text { Roundup PowerMax (or similar) } \\
+ \\
2,4-\text { D or dicamba products }\end{array}$ & $\begin{array}{l}22-32 \\
+ \\
\text { varies }\end{array}$ \\
\hline \multirow[t]{2}{*}{ Annual ryegrass ${ }^{1}$} & $\begin{array}{l}\text { Roundup PowerMax } \\
\text { (or similar) }\end{array}$ & $22-32$ \\
\hline & $\begin{array}{l}\text { Roundup PowerMax (or similar) } \\
+ \\
\text { Select Max }\end{array}$ & $\begin{array}{l}22-32 \\
+ \\
16\end{array}$ \\
\hline \multirow[t]{3}{*}{ Hairy vetch } & $\begin{array}{l}\text { Liberty } \\
+ \\
2,4-D \text { or dicamba products }\end{array}$ & $\begin{array}{l}22-29 \\
+ \\
\text { varies }\end{array}$ \\
\hline & $\begin{array}{l}\text { Roundup PowerMax (or similar) } \\
+ \\
2,4-\text {-D or dicamba products }\end{array}$ & $\begin{array}{l}22-32 \\
+ \\
\text { varies }\end{array}$ \\
\hline & $\begin{array}{l}\text { Gramoxone } \\
+ \\
2,4 \text {-D or dicamba products }\end{array}$ & $\begin{array}{l}8-12 \\
+ \\
\text { varies }\end{array}$ \\
\hline \multirow[t]{3}{*}{ Winter pea } & $\begin{array}{l}\text { Gramoxone } \\
+ \\
2,4 \text {-D or dicamba products }\end{array}$ & $\begin{array}{c}8-12 \\
+ \\
\text { varies }\end{array}$ \\
\hline & $\begin{array}{l}\text { Liberty } \\
+ \\
2,4-D \text { or dicamba products }\end{array}$ & $\begin{array}{l}22-29 \\
+ \\
\text { varies }\end{array}$ \\
\hline & $\begin{array}{l}\text { Roundup PowerMax (or similar) } \\
+ \\
\text { Sharpen }\end{array}$ & $\begin{array}{l}22-32 \\
+ \\
1 \mathrm{fl} \mathrm{oz}\end{array}$ \\
\hline
\end{tabular}




\begin{tabular}{|c|c|c|}
\hline Cover Crop & Herbicide Option & $\begin{array}{l}\text { Herbicide Rate } \\
\text { (fl oz/acre) }\end{array}$ \\
\hline \multirow[t]{2}{*}{ Crimson clover } & $\begin{array}{l}\text { Liberty } \\
+ \\
2,4-D \text { or dicamba products }\end{array}$ & $\begin{array}{l}22-29 \\
+ \\
\text { varies }\end{array}$ \\
\hline & $\begin{array}{l}\text { Roundup PowerMax (or similar) } \\
+ \\
2,4-D \text { or dicamba products }\end{array}$ & $\begin{array}{l}22-32 \\
+ \\
\text { varies }\end{array}$ \\
\hline \multirow[t]{2}{*}{ Rapeseed mustard } & $\begin{array}{l}\text { Roundup PowerMax (or similar) } \\
+ \\
2,4-D \text { or dicamba products }\end{array}$ & $\begin{array}{l}22-32 \\
+ \\
\text { varies }\end{array}$ \\
\hline & $\begin{array}{l}\text { Gramoxone } \\
+ \\
2,4-D \text { products }\end{array}$ & $\begin{array}{l}8-12 \\
+ \\
\text { varies }\end{array}$ \\
\hline
\end{tabular}

Table 3. List of cover crops and methods to consider for effective termination. Adapted from Bosak and Davis (2014).

\begin{tabular}{|c|c|c|c|c|}
\hline Cover Crop Type & Cover Crop Species & Herbicide & Roller-Crimper & Tillage \\
\hline \multirow[t]{6}{*}{ Small grains (grass type) } & Annual rye & Yes & Yes & Yes \\
\hline & Winter barley & Yes & Yes & Yes \\
\hline & Cereal/winter rye & Yes & Yes & Yes \\
\hline & Winter wheat & Yes & Yes & Yes \\
\hline & Oats & Yes & Yes & Yes \\
\hline & Barley & Yes & Yes & Yes \\
\hline \multirow[t]{5}{*}{ Legumes } & Red clover & Yes & No & Maybe \\
\hline & Crimson clover & Yes & No & Yes \\
\hline & Sweet clover & Yes & No & Maybe \\
\hline & Field pea & Yes & No & Yes \\
\hline & Hairy vetch & Yes & Yes & Yes \\
\hline $\begin{array}{l}\text { Mustard } \\
\text { (Brassica spp.) }\end{array}$ & Canola, radish, rapeseed mustard & Yes & No & Yes \\
\hline
\end{tabular}

